\title{
Análise do Requisito da Relevante Controvérsia Judicial em Sede de Ação Declaratória de Constitucionalidade
}

\author{
Analysis of Material Requirement of \\ Judicial Controversy in Place of \\ Declaratory Action of Constitutionality
}

\author{
Andréia Garcia Martin * \\ Silma Maria Augusto **
}

Resumo: Objetiva-se, com o presente, fazer uma breve análise do critério adotado pelo STF para definir o requisito da relevante controvérsia judicial em sede de Ação Declaratória de Constitucionalidade, que como requisito de admissibilidade perante o STF, gera debates conflituosos nesta Corte. Sob a análise da Jurisdição Constitucional e da legitimidade democrática do STF e, ainda, a natureza das decisões deste Tribunal como fator de indeterminação desse requisito, pretende-se demonstrar a perniciosidade de se utilizar a legitimação procedimental como sustentáculo da atividade do STF. Consignando-se, ante a natureza de suas decisões, a abertura dessa Jurisdição Jurisdicional, como guardião indissolúvel da Constituição.

Palavras-chave: Controle de constitucionalidade. Jurisdição

* Mestre em Direito pela Instituição Toledo de Ensino. Graduada em Direito pelo Centro Universitário de São José do Rio Preto. Professora do Centro Universitário de Votuporanga. E-mail: deiamartin1234@hotmail.com ** Mestre em Direito pela Instituição Toledo de Ensino. Graduada em Direito pela Faculdade de Direito do Oeste de Minas. Colaboradora do grupo de pesquisa Sobre Garantias de Acesso à Justiça e Concretização de Direitos. Professora do Curso de PósGraduação Lato Sensu em Direitos Humanos do Instituto DH. E-mail: silmaugusto@hotmail.com constitucional. Ação Declaratória de Constitucionalidade. Relevante controvérsia judicial. Legitimidade do STF.

Abstract: The purpose is, with this, make a brief analysis of the criterion adopted by the Supreme Court to define the requirement of the relevant judicial controversy thirst for Declaratory Action of Constitutionality, which as a condition of admissibility before the Supreme Court, this Court creates conflicting debates. Upon examination of the Constitutional Jurisdiction and the democratic legitimacy of the Supreme Court and also the nature of the decisions of this Court as a factor of uncertainty of this requirement is intended to demonstrate the destructiveness of using procedural legitimacy as the mainstay activity of STF. Consigning is, given the nature of its decisions, the opening of this Constitutional Jurisdiction, as unbreakable guardian of the Constitution.

Keywords: Constitutionality Control. Constitutional Jurisdiction. Declaratory Action of Constitutionality. Relevant Judicial Controversy. Legitimacy of the STF. 


\section{INTRODUÇÃO}

O controle de constitucionalidade brasileiro nos moldes como proposto na Carta Constitucional em 1988, após alguns anos de sua vigência mostrou-se insuficiente para responder acirradas discussões que insurgiam tanto no campo doutrinário quanto no âmbito do próprio Supremo Tribunal Federal.

Nesse panorama, eis que em 1993 com a edição da Emenda Constitucional n. 3 instituiu-se uma renovada aptidão ao Supremo Tribunal Federal, como guardião indissolúvel da Constituição da República que, somada as outras modalidades de controle da Jurisdição Constitucional, tais como a ação direta de inconstitucionalidade, terá o condão, também, de declarar a constitucionalidade, especificamente quando o dispositivo constitucional questionado pender controvérsia sobre esse atributo.

Dessa forma, temos como objetivo neste trabalho analisar o entendimento do Supremo Tribunal Federal (STF) sobre o requisito da relevante controvérsia judicial em sede de Ação Declaratória de Constitucionalidade (ADC). Vez que, para que essa espécie de ação constitucional tenha admissibilidade perante o STF é necessário que exista relevante controvérsia judicial do ato normativo ou lei que constitui objeto da ação. Sendo que a Lei n ${ }^{\circ} 9.868 / 99$ exige a comprovação do ato normativo controvertido, porém, não conceituou tal termo, apenas facultou ao STF cuidar da definição.

Percebe-se que a natureza do termo relevante controvérsia suscita grandes dúvidas por se tratar de questão ampla e subjetiva. Nesse contexto que reside os debates acirrados por juristas e julgadores. Assim, perquire-se: Qual o critério adotado pelo STF para definir o requisito da relevante controvérsia judicial em sede de ADC? A partir dessa indagação é que se pretende construir este breve artigo.

Para dissertar sobre esse assunto é fundamental fazer algumas considerações em relação ao posicionamento da doutrina e jurisprudência sobre o significado da Jurisdição Constitucional e a legitimidade do STF para ser o guardião e cumpridor da supremacia da Constituição frente às demais leis.

Ademais, sob o termo relevante controvérsia, pretende-se, neste estudo, fazer uma crítica numa perspectiva processual, compreendendo o que vem a ser a legitimação procedimental desenvolvida por Niklas Luhmann e Jünger Habermas ressaltando, brevemente, a dificuldade de aplicá-la na realidade brasileira com o fito de se estabelecer a legitimidade democrática 
do Tribunal Constitucional. E, ainda, abordar a influência da natureza das decisões proferidas pelo STF como fator de indeterminação do requisito da relevante controvérsia judicial em sede de ADC.

\section{JURISDIÇÃO CONSTITUCIONAL}

As constituições contemporâneas tiveram origem no constitucionalismo moderno. Tido como movimento político, social e cultural o constitucionalismo surgiu a partir de meados do século XVIII e impulsionado pelas Revoluções Francesa e Americana.

A existência de um Estado Constitucional, de uma lei fundamental que vincula todos os Poderes Públicos passou a ser base para construção do Estado de Direito. Isso quer dizer que o Estado de Direito ao fundar seus alicerces sob uma Constituição é considerado Estado Constitucional (CANOTILHO, 2003, p.245), vez que é a Constituição que alberga as normas que organizam o Estado (SILVA, 2011, p.38).

Nas lições de José Joaquim Gomes Canotilho são ideias fundamentais do constitucionalismo moderno expressões como ordenar, fundar e limitar o poder político, bem como reconhecer e garantir os direitos e liberdades do indivíduo (CANOTILHO, 2003, p.51).

Daí nasceu a ideia de supremacia e rigidez da Constituição. Sendo esses fatores preponderantes para instituir-se um sistema de controle. A ausência desses pressupostos tornaria inviável referir-se a um controle de constitucionalidade, principalmente porque este está relacionado à imposição de mecanismos de defesa da ordem constitucional, extraindo-se tanto da supremacia como da rigidez um aparelhamento positivado normativamente que tem o condão de dificultar os processos de mudanças constitucionais, bem como de garantir que seja preservada sua superioridade.

No entender de Flávia Piovesan é por isso que a própria Constituição traz em seu bojo instrumentos com o fito de garantir sua supremacia ${ }^{1}$, tendo como principal expoente o controle de constitucionalidade das leis. Sendo assim, a incompatibilidade de qualquer lei ou ato normativo com os dispositivos constitucionais nascem eivados do vício, sendo pendentes de anulação. Esse controle de constitucionalidade consiste na conformidade das leis

\footnotetext{
${ }^{1}$ É a partir desta preocupação em consolidar o constitucionalismo e tomar a Constituição a sério que surge o mecanismo de controle da constitucionalidade. (PIOVESAN, 2003, p.84).
}

REVISTA DO DIREITO PÚBLICO, Londrina, v.8, n.2, p.91-118, mai./ago.2013 
infraconstitucionais com a Constituição. Possibilidade que revela maior importância à lei superior (BASTOS, 1996, p.351), dessa forma, a Constituição se impõe no ápice da pirâmide normativa ${ }^{2}$.

Se pensarmos por este ângulo o Estado Democrático de Direito, em que se adota o modelo democrático tendo por núcleo central a Constituição, faz-se premente a existência de uma instância neutra, que seja curadora, guardiã, e que venha preservar a Constituição com base em sua supremacia, e tendo por sustentáculo a democracia. De forma que a Jurisdição ou Justiça Constitucional constitui-se pelo agrupamento de técnicas e instituições com o intuito de garantir a superioridade da Constituição, fator que possibilita o aumento do rol das matérias constitucionais a serem protegidas pela Corte.

Assim, o controle de constitucionalidade das leis se perfaz através de técnicas postas à disposição da Justiça Constitucional, que utiliza esse instrumento como baluarte da própria Constituição, valorando-a axiologicamente em face do ordenamento jurídico, deste modo "a Constituição se juridifica e judicializa" (OTTO, 2001, p.36), ganhando o status que lhe é inerente.

Igualmente, esta Jurisdição tem por premissa a defesa dos valores constitucionais básicos. Depreende-se, pois que "a Jurisdição Constitucional emergiu historicamente como um instrumento de defesa da Constituição, não da Constituição considerada como um puro nome, mas da Constituição tida como expressão de valores sociais e políticos" (SILVA, 2011, p.557).

Diante de tal evolução, à vista do processo de redemocratização, que teve seu ápice com a promulgação da Constituição de 1988, fomentou-se o fortalecimento e a expansão do Poder Judiciário. Processo que resultou num mastodôntico aumento da função jurisdicional qualificada como constitucional, que ultrapassou o mero papel de realizar o controle de constitucionalidade, passando também a exercer as funções de fiscalização da Administração Pública e do Legislativo. Além de se tornar o tutor dos direitos fundamentais em suas mais variadas dimensões, ensejando o debate com a sociedade ante a abertura processual proporcionada por alguns institutos típicos, que o pluraliza e o democratiza.

Isso acontece especialmente, por exemplo, no caso de se admitir no direito pátrio a figura do amicus curiae, instituto do direito processual que tem por finalidade possibilitar outras pessoas físicas ou jurídicas de oferecer uma forma de assistência qualificada ao Judiciário (AUGUSTO, 2010, p.133-134).

\footnotetext{
${ }^{2}$ A história constitucional revela, em seu desenvolvimento, a preocupação de preservação da Constituição, enquanto norma suprema da ordem jurídica. (PIOVESAN, 2003, p.83).
} 
Nesse sentido, Mônia Clarissa Hennig Leal afiança que as mudanças e a evolução do Estado acarretaram a modificação da Constituição e, consequentemente, o próprio conceito de Jurisdição Constitucional, asseverando que "assim como a própria Constituição se desenvolveu na perspectiva do Estado, também o papel da garantia e as formas de atuação da Jurisdição Constitucional se modificaram na esteira destas transformações" (LEAL, 2007, p.5).

$\mathrm{Na}$ atual conjuntura nacional, as mutações ocorridas na sociedade passam a adentram aos órgãos estatais, tornando complexo o discurso sobre a necessidade de redefinição dos limites da separação dos poderes, porém, tal discurso não pode colocar em risco a supremacia constitucional, especialmente, no que se refere à garantia dos direitos fundamentais e sociais consagrados constitucionalmente.

Dessa forma, "o controle de constitucionalidade, tal como desempenhado no Estado contemporâneo, deve enquadrar-se no contexto da democracia e reforçá-la" (ROTHERBURG, 2005, p.104). Vislumbra-se assim, que o Tribunal Constitucional é legitimo para desempenham amplamente a Jurisdição Constitucional, tendo por função precípua de defesa da Constituição, diretamente ligado a perseguir o compromisso constitucional assumido pelos Poderes de Estado na realização dos preceitos constitucionais.

No sistema brasileiro, essa instituição de defesa do Texto Constitucional tem como principal guardião o Supremo Tribunal Federal, órgão responsável pela fiscalização do cumprimento da Constituição. No entanto, este não equivale às Cortes Constitucionais existentes no mundo, pois sua formação e desenvolvimento ocorreu de forma deverás diferenciada, principalmente pelo fato do controle de constitucionalidade das leis não se restringirem a um único órgão jurisdicional competente, sem contar que nele também se concentra a competência de Corte judicial recursal.

Portanto, à vista da Constituição vigente, tem-se que esta forma de jurisdição combina dois sistemas, ou seja, o sistema difuso e concentrado do controle de constitucionalidade das leis. Assim, nomear o Supremo Tribunal Federal como um "Tribunal Constitucional" apresenta relevância mais patente nos casos de controle concentrado de constitucionalidade de leis ou atos normativos, sendo essa prerrogativa explicitamente outorgada no art. $102 \mathrm{da}$ Constituição Federal ${ }^{3}$.

\footnotetext{
${ }^{3}$ A expressão Tribunal Constitucional não está sendo empregada, aqui, no sentido eminentemente técnico adotado por José Afonso da Silva (2011, p.558).
} 
Nesse sentido Emílio Santoro afirma que:

[...] a atribuição do controle de constitucionalidade das leis a um órgão jurisdicional especial não pode ser considerada um ponto de chegada na trajetória do Estado de Direito: é somente uma etapa num itinerário. A estrada que o Estado de Direito percorreu, de pari passu com o progressivo fortalecimento do papel das Cortes constitucionais, é marcada [...] pelo reconhecimento do papel dos juízes na criação das normas, pela crescente tendência dos órgãos legislativos e administrativos em lhes delegar delicadas decisões jurisdicionais, e pela ampliação do acesso aos cidadãos à Justiça, para resolver controvérsias que tradicionalmente eram solucionadas por autoridades sociais ou administrativas (SANTORO, 2005, p.15).

Depreende-se, pois, que "a instituição da jurisdição constitucional não se acha de forma alguma em contradição com o princípio da separação dos poderes, ao contrário, é uma afirmação dele" (KELSEN, 2003, p.152). Ou seja, encontrase intimamente relacionada, pois, o constitucionalismo moderno tem a façanha de conjugar institutos que por muito tempo existiram de formas apartadas, com o condão de promover os ideais democráticos compatibilizados com a plena proteção aos direitos fundamentais. Acoplando-se, tais institutos, na atuação da Jurisdição Constitucional por meio do controle de constitucionalidade.

\subsection{Breve escorço das origens do Controle de Constitucionalidade}

As origens do controle judicial de constitucionalidade advêm de um clássico julgado da Suprema Corte norte-americana, o caso Marbury versus Madison, tornando-se paradigmático para o constitucionalismo universal. Sob os auspícios de tal julgado, na ocasião presidido pelo juiz John Marshall, podese extrair alguns pontos fundamentais do controle jurisdicional de constitucionalidade norte-americano.

Inicialmente, compreende-se por lei fundamental a própria Constituição escrita, que como declaração da vontade originária do povo, no mesmo momento que lhe outorga poderes os restringe, representando a adoção do princípio da supremacia da Constituição. Ademais, tal modelo dá respaldo à possibilidade de não se aplicar - seja por qualquer juiz, individualmente, ou por Tribunal, em sua forma colegiada - norma presente na legislação ordinária que se vislumbre contrária à Constituição - dada sua supremacia - em questões concretas que conjecturam um conflito efetivo (controle difuso). Assim, tal norma fica pendente 
somente a uma declaração pelo Tribunal Constitucional de sua inconstitucionalidade, vez que, tem o juiz ou Tribunal tão-só a competência de julgar as contendas concretas que se acendem entre litigantes diversos.

Destarte, o direito de declarar inconstitucionalidade das leis, pela Corte, passa a existir pelo fato de uma delas, evocada por uma das partes, como embasamento de seu direito, encontrar-se em conflito com a Constituição. Esta possibilidade, facultada à Corte, representa a função mais importante desta no modelo americano. Quando proferida a inconstitucionalidade a lei será considerada nula, não produzindo qualquer efeito. (DANTAS, 2001).

Em contrapartida, frente a esse sistema difuso, originário do judicial review norte-americano, temos o sistema de Jurisdição Constitucional concentrada, tal sistema é denominado também de sistema austríaco, tendo suas origens na obra de Hans Kelsen (2003), e como o próprio nome já diz a decisão deste controle se concentra em um único órgão competente, qual seja, a Corte Constitucional. $\mathrm{O}$ fundamento deste sistema é desenvolver um processo objetivo, valendo-se da lei em tese para a defesa da Constituição.

Sob este prisma é que se insere o histórico do controle de constitucionalidade no Brasil. Na história das Constituições brasileiras observase a presença do sistema de controle de constitucionalidade a partir da Constituição de 1891, em que se apresentava, tão-somente sob a forma difusa. Esse modelo permaneceu na Constituição de 1934, porém, para que o controle de via incidental possuísse efeito contra todos, era necessária a participação do Senado, se assemelhando ao modelo que existe hoje.

Contudo, somente no ano de 1965 foi introduzido o controle concentrado de constitucionalidade no Brasil, incluída, através da Emenda Constitucional $n^{\circ}$. 16 à Constituição de 1946, passando a figurar ao lado do controle difuso.

Com a o advento da Constituição de 1988 manteve-se o cenário apresentado acima, qual seja, o controle difuso e o concentrado, este, porém, figurando apenas a Ação Direta de Inconstitucionalidade. Ao lado de outras importantes modificações, como a previsão da ação direta de inconstitucionalidade por omissão, da ação de descumprimento de preceito fundamental e do mandado de injunção.

Nesta senda, eis que se enseja a abertura do processo constitucional através da Lei no $.9 .868 / 99$ que permite a intervenção no processo de órgãos ou entidades com o intuito de fomentar uma maior entronização de elementos democráticos para tornar tal procedimento autenticamente legitimado. 
Nesse sentido, Luiz Roberto Barroso assegura que:

[...] tem-se travado, nos últimos anos, uma ampla discussão sobre o controle de constitucionalidade pelo Judiciário e seus limites. Sustenta-se que os agentes do Executivo e do Legislativo, além de ungidos pela vontade popular, sujeitam-se a um tipo de controle e responsabilização política de que os juízes estão isentos. Daí afirmar-se que o controle judicial da atuação dos outros Poderes dá lugar ao que denominou de "countermajoritarian difficulty" (dificuldade contra-majoritária). Notadamente os segmentos conservadores têm questionando o avanço dos tribunais sobre espaços que, segundo crêem, deveriam ficar reservados ao processo político. (BARROSO, 1996, p.157).

Dessa forma, a Jurisdição Constitucional além de manter uma permanente tensão com a democracia, abre-se para uma nova modelagem de seus contornos, buscando sua legitimação democrática, que não sendo representativa, insurge no campo de diálogo e discussão que a Corte alvitra, o que fomenta a legitimidade do Tribunal Constitucional em interferir nas decisões tomadas pelos representantes do povo.

\subsection{Da instauração do Supremo Tribunal Federal}

O Supremo Tribunal Federal deu os primeiros indícios de surgimento com a proclamação da República em 15 de novembro de 1889, sua instauração, em reprodução aos moldes da Corte norte-americana, teve a base do anterior Tribunal de Justiça do Império que não vingou por sua inexpressiva atuação, que diante da existência do Poder Moderador era confiado ao Imperador com poderes ilimitados.

Com a vigência do Decreto $n^{\circ} .510$ de 22 de junho de 1890 deu-se início a instauração do STF. Porém, somente pelo Decreto $n^{\circ} .848$ de 11 de outubro de 1890 é que o Supremo Tribunal de Justiça do Império transmudou-se em Supremo Tribunal Federal. Assim, na primeira Constituição da República, a de 1891, em que o art. 59, $\S 1^{\circ}, \mathrm{b}$, tratou de forma expressa, determinando sua função precípua, qual seja: a de declarar a inconstitucionalidade das leis; inaugurando o prelúdio do controle jurisdicional de constitucionalidade de leis no Brasil.

As demais Constituições que se sucederam pouco modificaram no quadro geral do STF. Já com a Constituição Federal de 1988 o constituinte desejou conceder ao STF um status similar ao de uma Corte Constitucional, outorgando- 
lhe a competência basilar de guarda da Constituição, devendo velar, indelevelmente, por sua supremacia.

Assim, diante do quadro que se afigura o atual estágio do constitucionalismo contemporâneo, em que se avulta os direitos fundamentais, deve o Tribunal Constitucional tomar um lugar de destaque entre a tríade dos Poderes do Estado, em que velar pela guarda e supremacia da Constituição é velar pela própria vivificação da concretização dos direitos fundamentais assegurados em seu Texto.

A partir da realidade sócio-política-jurídica brasileira - marcada pela desigualdade social e omissões do Poder Legislativo e Executivo - o STF começou a não só albergar as temáticas do controle de constitucionalidade em suas pautas, pois, ele como Tribunal Constitucional é órgão que tem tal legitimidade, passou também a aperfeiçoar a pretensão negativa do legislador constituinte, na defesa dos direitos constitucionais fundamentais, principalmente de minorias, dotando-se de uma especial legitimidade democrática.

Nesta senda, pode-se afirmar que o Tribunal Constitucional é democrático e possui legitimidade principalmente por sua função contra-majoritária ${ }^{4}$, com o propósito de proteger os direitos fundamentais, bem como, a própria ordem jurídico-constitucional.

\section{A LEGITIMIDADE DEMOCRÁTICA DO SUPREMO TRIBUNAL FEDERAL}

Considerando que o Texto Constitucional seria o resultado da reunião de forças, interesses e bens contraditórios. Ou seja - segundo o entendimento de Niklas Luhmann (2002) -, por ser a Constituição um complexo mecanismo que enseja o acoplamento estrutural entre os sistemas político e jurídico, em que se favorece a troca de conhecimento entre estes sistemas, atua como um instrumento de interferência recíproca entre eles. Assim, por esse motivo, a Constituição através da abertura cognitiva ao seu ambiente promoveria a captação de influxos da realidade legitimando-se democraticamente.

\footnotetext{
${ }^{4}$ Referido termo é utilizado por Luiz Roberto Barroso, valendo-se da expressão cunhada por Alexander Bickel "dificuldade contra majoritária" (BICKEL, 1996, p. 16 apud BARROSO, 2009, p.285). Com o intuito de discutir a legitimação democrática do Poder Judiciário, ponderando que pelo fato de seus membros serem agentes públicos, porém não eleitos, haveria comprometimento da legitimidade deste Poder, vez que seus membros têm o poder de deixar de aplicar leis elaboradas pelo Poder autenticamente constituindo pelo voto popular, ao se vislumbrar a incompatibilidade dessas com a Constituição Federal.
}

REVISTA DO DIREITO PÚBLICO, Londrina, v.8, n.2, p.91-118, mai./ago.2013 
Dessa forma, assevera Luhmann que é através da Constituição que se estabelecem as zonas de contato entre os sistemas jurídico e político. Instala-se uma recíproca irritabilidade entre esses dois subsistemas sociais. Desencadeando-se as maiores possibilidades do sistema jurídico registrar decisões políticas em forma jurídica, além de corroborar para que a política se utilize do direito para concretizar seus objetivos (LUHMANN, 2002, p.539541). A Constituição, então seria comum a ambos os sistemas, e o Tribunal Constitucional, segundo a visão de Luhmann seria o centro do sistema jurídico interno, ocorrendo o acoplamento dos subsistemas em suas decisões.

Nessa linha de pensamento, compete ao STF, por se situar no centro dessas trocas de informações e no cerne decisório da Jurisdição Constitucional, efetivar a Constituição, valendo-se, por consequência, de tal acoplamento estrutural entre os sistemas. Logo, por encontrar-se numa posição ambivalente garante o pleno funcionamento dos "códigos da política e do direito", com influências mútuas nos sistemas.

Portanto, a Jurisdição Constitucional que se afigura no Estado Constitucional deve desempenhar uma interpretação da Constituição com um juízo permeado da realidade atendo-se às múltiplas possibilidades e vicissitudes inerentes a ela.

Sob essas premissas, antes de se partir à análise da legitimidade do Supremo Tribunal Federal, faz-se necessário ressaltar a distinção entre duas formas de legitimidade, quais sejam, uma referente à própria Jurisdição Constitucional e a outra no que aduz ao exercício dessa jurisdição.

A primeira legitimidade ínsita à Jurisdição Constitucional, diz respeito à competência que o legislador constituinte, por ocasião da Assembleia Nacional Constituinte, assegurou ao Tribunal Constitucional, sendo este legítimo pelo simples fato de existir; por esta legitimidade lhes são outorgadas qualidades estáticas, de ordem institucional.

Infere-se, ainda, que dessa legitimidade formal extrai-se algumas categorias, quais sejam: uma condizente à vontade normatizada na Constituição Federal pelo Poder Constituinte Originário, em que a maioria atual sucumbe face da norma constitucional que disponha em sentido contrário (função contramajoritária). E outra, em que a legitimidade da Jurisdição Constitucional confundese com sua competência, isto é, só por seus atributos, tais como, órgão oficial estatal e competentemente nomeado. E ainda, uma legitimidade democrática indireta que se alcançaria em virtude dos membros dos poderes que fazem a escolha dos Ministros do Tribunal Constitucional serem representantes do povo. 
Contudo, tais categorias deixam aquém a conquista de uma legitimidade verdadeiramente democrática.

$\mathrm{O}$ concernente à legitimidade de exercício, que teria características em constante dinâmica, sendo predominante um cunho axiológico, teria sua atuação voltada sob a pretensão de proteger a ordem constitucional, circulando entre os ambientes do Direito e da Política. Distingue-se em legitimidade técnica, por referir-se à independência no exercício da função jurisdicional, que apesar da falta de representatividade de origem eletiva ao Tribunal Constitucional não lhe prejudica a plena conquista de legitimidade, ainda que de caráter democrático.

Ademais, a defesa de direitos constitucionais fundamentais de minorias pelo Tribunal Constitucional será dotada de uma especial legitimidade democrática, tendo em vista tão-só pelo fato de se efetivar tais direitos o torna legítimo. Assim, o ponto culminante que se coloca em xeque a respeito da legitimidade do Tribunal Constitucional se dá quando este se coloca numa posição oposta “às decisões dos demais 'poderes' (função arbitral), contra a lei da maioria (função estruturante) ou diretamente contra a própria vontade popular ou, ainda assume decisões próprias [...]" (TAVARES, 2005, p. 496).

Em algumas situações, quando "a missão do Tribunal Constitucional se projeta, assim, para além da mera função de legislador negativo, guardião da coerência sistêmica do ordenamento jurídico" (BINENBOJM, 2001, p.82), verifica-se a expansão de sua atuação para alcançar integralmente a legitimidade de natureza democrática, pois passa a ter a função "de articular o debate público em torno dos princípios constitucionais [...]" (BINENBOJM, 2001, p.82), donde se apóia no ínfimo intuito de concretizar os direitos constitucionais fundamentais.

Ora, vislumbra-se que, o que fornece legitimidade democrática ao Tribunal Constitucional é sua função jurisdicional voltada especificamente para os anseios verdadeiramente democráticos da sociedade contemporânea, desempenhando importante papel na defesa do pluralismo das minorias e no controle do Poder Público.

\subsection{Legitimidade Procedimental: Niklas Luhmann versus Jünger Habermas}

Ainda no que diz respeito à legitimidade no exercício da Jurisdição Constitucional há uma corrente procedimentalista que gira e torno da teoria proposta por Niklas Luhmann (1980) e Jünger Habermas (2002), que apesar de serem da mesma vertente adotam posicionamentos divergentes. 
De acordo com a doutrina de Niklas Luhmann que fundamenta sua obra na teoria dos sistemas, tem-se que somente o procedimento legitima o Tribunal Constitucional, isto é, para o Tribunal Constitucional realizar a Justiça Constitucional deverá levar em conta tão-só o procedimento pré-estabelecido. Com essa teoria procedimental da Jurisdição Constitucional ele defende que o procedimento é inerente às decisões judiciais e, por si só, é condição suficiente para a sua legitimação, mesmo que seus posicionamentos tragam grande repercussão social.

O seu conceito de legitimidade não permite uma ligação direta com os interesses dos atores sociais, não se importando se as decisões judiciais obtenham consenso em virtude da aceitação dos jurisdicionados ao conteúdo da sentença. Assim, não há o imperativo de se construir um espaço público para a participação dos jurisdicionados como defendido por Jünger Habermas. Com efeito, Luhmann entende que a atividade jurisdicional transforma-se em legítima a partir do momento que são aptas a coligir uma aceitação diante da decisão.

Assim, a legitimidade, de acordo com o entendimento luhmanniano, advém da função que o procedimento judicial representa no desembocar em uma decisão judicial, ou seja, o procedimento e o processo judicial têm a função de, necessariamente, findar-se numa decisão judicial. Haja vista que a Jurisdição Constitucional somente se legitimará a partir do momento que seja apto a suscitar uma generalização que faça com que as decisões proferidas pelos órgãos do Poder Judiciário sejam aceitas, independentemente de serem a mais acertada aos casos concretos ou não.

Portanto, a legitimidade está vinculada a um procedimento que deságue numa decisão, mesmo que, normalmente, não decorra esta de um consenso, nem seja a mais justa, mas terá o condão, simplesmente, de generalizar as expectativas presentes na sociedade

Nessa perspectiva, Luhmann nos apresenta a definição de legitimidade como uma "disposição generalizada para aceitar decisões de conteúdo ainda não definido, dentro de certos limites de tolerância" (LUHMANN, 1980, p.30).

Dessa forma, o Tribunal Constitucional somente torna-se legítimo, bem como suas decisões, quando pauta-se em um procedimento operacionalmente fechado agindo sob o código binário licito/ilícito. Não levando em conta a sociedade, nem a realidade para as tomadas de decisão.

Contudo, necessário se asseverar que a posição de Luhmann queda-se um tanto quanto inadequada, pois, não será simplesmente o procedimento que legitimará, mas sim um procedimento adequado para que se concretize a 
Constituição e os direitos fundamentais, devendo o referido Tribunal Constitucional estar aberto à realidade e ao debate com a sociedade.

Dentro desse panorama, Habermas (2002, p.342) afiança que a legitimação pelo procedimento, sem estar associado a uma sintonia direta com o espaço público, é uma perfumaria jurídica, no afã unicamente de promover uma ilusória estabilização dentro do sistema, em que as controvérsias são exauridas no próprio ordenamento normativo, resolvidas pelo código jurídico binário lícito/ilícito.

Habermas atua no sentido de compatibilizar a soberania popular com os direitos fundamentais, pois além de serem elementos imprescindíveis ao processo democrático, os direitos fundamentais precisam ficar protegidos dos caprichos da maioria legislativa. A atuação que legitima o Tribunal Constitucional é aquela voltada à proteção dos direitos constitucionais fundamentais. Assim, "em face de um procedimento como esse, legitimamente reconhecido, ainda se pode fazer valer a diferença entre um resultado 'válido' e um resultado 'racionalmente aceitável' (no âmbito institucional dado)” (HABERMAS, 2002, p.343).

Neste sentido, tem-se o posicionamento de Friedrich Müller, senão vejamos:

O discurso de legitimação de uma democracia não só obriga a mesma a ser democrática no seu conteúdo - abstraindo do fato de que o significado desse adjetivo 'democrático' pode ser matéria de grandes controvérsias. Ele deveria, sobretudo realizar também no seu próprio procedimento o que designa, deveria, portanto, ser correlativamente estruturado, i.é: não formular afirmações em bloco, que se imunizam contra a discussão, não apresentar-se qual dedução cogente, não falar por intermédio de resultados antecipados. Muito pelo contrário, a legitimidade - como também a normatividade jurídica - é um processo e não uma substância, uma essência ou mesmo uma qualidade de textos (MÜLLER, 2003, p.107).

A força que legitima a Jurisdição Constitucional sustenta-se no estabelecimento de procedimentos interligados a uma comunicação com índole para constituir uma opinião pública, fundando uma política deliberativa. Neste sentido, tem-se que:

[...] o Tribunal Constitucional precisa examinar os conteúdos controvertidos especialmente no contexto dos pressupostos comunicativos e condições procedimentais do processo de legislação democrático. Tal compreensão 
procedimentalista da Constituição imprime uma virada teórico-democrática ao problema da legitimidade de controle de constitucionalidade. (HABERMAS, 2003a, p.326).

Há uma abertura discursiva na Jurisdição Constitucional buscando a construção racional das decisões sobre controle de constitucionalidade, que se dará por meio do debate. Dessa forma, o STF torna-se um espaço público por excelência para o acolhimento desse debate, em que as questões constitucionais ao serem discutidas promovem a edificação de decisões que coadunam com a realidade da sociedade.

No que tange à defesa dos direitos fundamentais, é no Tribunal Constitucional em que tais direitos, dada a sua fundamentalidade, encontram um espaço adequado ao amplo debate, especialmente em sede de controle de constitucionalidade. Assim, a Jurisdição Constitucional, por meio deste controle, tem a obrigação de garantir o devido processo legislativo e os direitos fundamentais, com fundamento no desígnio de que o constitucionalismo e a democracia não são contrários, mas sim ao agirem em conjunto promovem a integral concretização dos direitos fundamentais.

Os órgãos judiciais encarregados de velar pelo respeito à constituição, especialmente o Tribunal Constitucional desempenham um papel importante na obtenção e manutenção do consenso, à medida que lhes competi decidir em termos jurídicos sobre opções políticas que lhes são submetidas, e que lhes podem ter sido deliberadamente deixadas pelas instâncias políticas, que não conseguiram obter o consenso e a autoridade necessária para mantê-lo (ROTHERBURG, 2005, p.102).

Apesar de Habermas ter se fundado numa legitimidade procedimentalista quanto à atuação do Tribunal Constitucional, ele admite que para que este não se torne um reduto autoritário e arbitrário de poder, necessário se utilizar da lição de Peter Häberle (2002) da Sociedade Aberta aos Interpretes da Constituição. Asseverando que haverá a possibilidade de abertura do Tribunal Constitucional aos influxos de outros redutos da sociedade donde se extrairá a realidade social, assim, será possível que se coloque um fim a presumida falta de legitimidade do STF, que é suprida com o elevado grau de criatividade que lhe é outorgada pelo Poder constituinte Originário. Tendo em vista que a abertura à interpretação criativa à Jurisdição Constitucional fomenta a 
pluralização do debate constitucional conferindo um elevado grau de legitimidade social as suas decisões.

Portanto, pode-se afiançar que, hodiernamente, a Jurisdição Constitucional brasileira alberga um arquétipo procedimental que apresenta alternativas e condições as quais possibilitam, de modo fortemente aberto, a ingerência de uma multiplicidade de sujeitos, interesses, assuntos e pontos de vista dentro do processo constitucional.

A abertura comunicacional para o exterior faz-se necessária em todo e qualquer sistema, com o intuito de mantê-los vivos, e em constante evolução, conservando-os em conformidade com as necessidades e ocorrências do meio. Assim, a fresta que desabrolha no sistema constitucional por meio da atividade da Jurisdição Constitucional à interpretação de novas necessidades da realidade torna-o um concretizador impar do Texto Constitucional.

Com efeito, a abordagem do controle concentrado de constitucionalidade, em especial da Ação Declaratória de Constitucionalidade, a presença desse novo perfil, que se apresentam as decisões do STF influenciarão, sobremaneira, o requisito da relevante controvérsia judicial. Fato que será explicitado e demonstrado em tópico posterior.

\section{AAÇÃO DECLARATÓRIA DE CONSTITUCIONALIDADE}

AAção Declaratória de Constitucionalidade no momento da promulgação da Constituição de Federal, em 05 de outubro de 1988, não figurou em sua redação original, tendo sido incluída, na Carta somente a partir da Emenda de Revisão. Parafraseando Lênio Streck, através da ADC foi instituída uma ação sem precedentes no Direito comparado (STRECK, 2004, p.587).

Assim, a ADC foi criada na ocasião da reforma tributária de 1993. Mediante a Emenda Constitucional n ${ }^{\circ}$. 3, datada em 17 de março de 1993, em que foi disciplinada e atribuída competente para seu julgamento o Supremo Tribunal Federal. Uma vez decidido o mérito da ADC seus efeitos tem eficácia erga omnes (contra todos) e é vinculante em relação a outros órgãos do Poder Executivo e Judiciário (MENDES, 2007, p.90-91).

Registre-se que, a criação da ADC teve motivação econômica e política, pois no momento em que foi introduzida no sistema jurídico brasileiro o Governo Federal implantava reformas no sistema econômico e tinha receio de que decisões judiciais de primeira instância interrompessem a implantação das medidas. Ademais, conforme já anteriormente abordado, o controle de constitucionalidade, reflexamente aqui representado pela $\mathrm{ADC}$, tem como escopo principal a defesa 
da Constituição, ensejada pela manutenção da harmonia constitucional que seria conformada com a própria garantia dos direitos fundamentais.

Segundo Walter Claudius Rotherburg (2002, p.269) o "controle de constitucionalidade, dentro do contexto mais amplo da jurisdição constitucional, tende a desenvolver-se preponderantemente em um destes dois sentidos: a tutela dos direitos fundamentais ou a estabilidade do governo ('governabilidade')".

A Lei $n^{\circ}$. 9.868/99 foi, definitivamente, capitaneada pelo governo Federal. Por isso da preponderância do sentido da estabilidade do governo, em detrimento dos direitos fundamentais. Sem, contudo, olvidar que ambos estão intimamente ligados, não havendo exclusão de qualquer um deles, por serem de grande importância ao controle de constitucionalidade.

Com efeito, a primeira discussão sobre o novo instituto de controle de constitucionalidade versou sobre a inconstitucionalidade da própria emenda que havia estabelecido a citada ação constitucional. O principal argumento da corrente que defendia a inconstitucionalidade desse instituto colocava como óbice a ausência do contraditório. Conforme se pode notar do posicionamento defendido por Maria de Lourdes Seraphico Peixoto da Silva (1994, p.141), que afiança que: "a sociedade não tem como se defender já que não poderá integrar a lide. O Estado pode exigir manifestação definitiva contra a sociedade sem que ela participe do processo".

Entretanto, ante a brilhante exposição da autora, este entendimento requer outro olhar, vez que, vislumbra-se por parte de seu posicionamento que ela se olvidou da possibilidade que trouxe o $\S 2^{\circ}$ do art. $7^{\circ}$ da Lei $n^{\circ} .9868 / 99$, qual seja, a manifestação em sede de ADC de outros órgãos ou entidades, ou seja, permitiuse que a sociedade civil organizada possa influir no processo que sejam partes, desde que tenham um interesse social relevante, interventor este chamado de amicus curiae (amigo da corte). Esse instituto tem a função de socializar, pluralizar e democratizar o debate no exercício da Jurisdição Constitucional.

Porém, conforme acima referido, sobre o primeiro argumento da corrente que considera inconstitucional a Emenda que instituiu essa ação constitucional, sob a alegação da falta de contraditório, o STF pacificou o assunto ao julgar que o processo de ADC é objetivo e por isso não fere o princípio do contraditório (PINHO, 2005, p.127-129).

A explanação das características ínsitas da ADC ganham relevo em face da íntima relação que essas detêm com o requisito da relevante controvérsia judicial, características essas que se passa a analisar. 


\subsection{Características da Ação Declaratória de Constitucionalidade}

Pela própria forma de composição da ADC percebe-se que esta possui um objeto sui generis, qual seja: a controvérsia a respeito da constitucionalidade da lei ou ato impugnado, conformando-se com a principal finalidade dessa ação constitucional que é a de declarar, por meio de decisão proferida pelo STF, a constitucionalidade de lei ou ato normativo. Nesse sentido, constou da ADC ${ }^{\circ}$. 1 a conceituação de tal instituto. Assim,

A ação declaratória de constitucionalidade insere-se no sistema de controle em abstrato de constitucionalidade de normas, cuja finalidade única é a defesa da ordem jurídica, não se destinando diretamente à tutela de direitos subjetivos. Por isso mesmo, deve ser necessariamente estruturada em um processo objetivo, como ocorre com a ação direta de inconstitucionalidade, isto é, um processo não contraditório, sem partes, embora possam ser ouvidos os órgãos que participaram da elaboração da lei ou do ato normativo (BRASIL, 1995).

Destaque-se, dessa forma, que por ocasião da própria evolução do controle de constitucionalidade no Brasil é que se deu ensejo ao surgimento da ação constitucional que pretendia declarar a constitucionalidade, a priori. Contudo, sua criação não teve o intuito de, simplesmente, declarar a constitucionalidade, mas também, detinha o desígnio consequente de eliminar conflitos de leis ou atos normativos frente à Constituição Federal.

Assim, apesar da aparente constitucionalidade das normas constantes do Texto Constitucional, sendo estas presumidas legítimas, surgiu a necessidade da existência de um instituto que colocasse fim a controvérsia da constitucionalidade ou inconstitucionalidade da lei ou ato normativo.

No entanto, Ana Maria Scartezzini (1996, p.4) entende que esta presunção não é absoluta, haja vista que "o administrado pode demonstrar que o ato contraria o ordenamento jurídico (constitucional), mas essa prova deve ser feita, pois milita em sentido contrário a legitimidade, em tese, do provimento emanado da Administração" e do Congresso Nacional.

De acordo com esta autora "a declaração de constitucionalidade tem por escopo, em matérias de interesse relevante para o Governo Federal, evitar a proliferação de lides, nos diversos graus de jurisdição, com a possibilidade de ocasionar decisões contraditórias, em prejuízo da segurança jurídica" (SCARTEZZINI, 1996, p.8). 
Observa-se que esse pensamento da autora foi produzido anteriormente à edição da Lei $n^{\circ} 9.868 / 99$, atualmente tal posicionamento não tem mais razão de ser, pois o condão primacial da ADC é resguardar a supremacia constitucional do ordenamento jurídico brasileiro. Dentro desta concepção é imprescindível, portanto, o requisito da efetiva existência de controvérsia judicial a respeito de determinada lei ou ato normativo federal.

Sabe-se que a EC $n^{\circ}$. 03/93 trouxe com a ADC uma nova figura processual tornando-a autônoma, visto que possui um disciplinamento próprio. Sua natureza é de processo de Jurisdição Constitucional voluntária, inexistindo partes. Nessa perspectiva Gilmar Mendes é categórico em afirmar que o processo pelo qual é exercido o controle concentrado é chamado de processo objetivo, pois não tem partes componentes de uma lide comum, é destinado apenas à defesa da Constituição (MENDES, 2007, p.3).

Justifica-se, dessa forma, a necessidade da ação que declara a constitucionalidade de lei ou ato normativo, principalmente, como anteriormente citado, por ocasião da possibilidade de efeito vinculante em sua decisão, o que vedaria qualquer outra que a contrariasse.

Deve-se ressaltar, ainda, que a criação dessa ação constitucional também reflete a finalidade de uniformizar a jurisprudência, especialmente, em matéria constitucional. Não visa simplesmente resguardar a presunção de validade das leis e atos normativos, todavia, sua decisão final amplia-se para abrigar a Administração Pública e o Judiciário. Isto é, refere-se a uma ratificação da presunção.

Busca-se, por outro lado, irremediavelmente, distanciar a ordem constitucional da suscitação de incerteza ou insegurança jurídica, com a consignação de uma orientação semelhante a respeito da matéria, pois, com a ADC almeja-se, em razão da segurança jurídica, abolir a controvérsia, a imprecisão, suplantar a polêmica em torno da constitucionalidade de uma lei ou ato normativo federal. Sob esta proeminente premissa se parte à análise do requisito da relevante controvérsia judicial em sede de ADC.

\section{O ENTENDIMENTO DO SUPREMO TRIBUNAL FEDERAL SOBRE O REQUISITO DA RELEVANTE CONTROVÉRSIA JUDICIAL EM SEDE DE AÇÃO DECLARATÓRIA DE CONSTITUCIONALIDADE}

A Lei $n^{\circ}$. 9868/99, que instituiu o processo e julgamento da ADC - bem como da Ação Direta de Inconstitucionalidade -, em seu art. 14. Inc. III, faz 
referência à necessidade da presença de um requisito imprescindível para a própria propositura desta ação, qual seja, a relevante controvérsia judicial face ao rompimento da presunção de constitucionalidade. Contudo, apesar de consignar essa necessidade, a lei foi silente quanto à caracterização desse requisito, deixando tal função à Corte Constitucional.

Iniciando-se tal caracterização torna-se imperioso se advertir que o entendimento da Corte, no julgamento da $\operatorname{ADC} n^{\circ} .8$, foi no sentido de que a controvérsia judicial precisa ser efetiva para que realmente se demande o ajuizamento de ADC. ${ }^{5}$

Com efeito, necessário se ressaltar que para se caracterizar a relevante controvérsia judicial será necessário se configurar a dúvida no momento de aplicação de uma lei. Essa dúvida precisa ser demonstrada com decisões conflitantes entre órgãos judiciais de primeira instância, bem como, que a controvérsia cause insegurança jurídica e perplexidade social.

Registre-se que a utilização dessa espécie de ação constitucional, apesar de deter uma falaciosa aparência de simples conformação da constitucionalidade ou não do objeto da ação, assemelhando-se a um instrumento de consulta ao Poder Judiciário, esta não equivaleria a tal ensejo, conforme se pôde depreende do julgamento da ADC $\mathrm{n}^{\circ}$. 8, sendo que o pressuposto de admissibilidade para propositura dessa ação se conforma à efetiva controvérsia em torno da legitimidade constitucional de determinada lei ou ato normativo. Essa efetividade se configura com a existência de pronunciamentos judiciais antagônicos, caso contrário a ADC tornaria um

\footnotetext{
${ }^{5}$ EMENTA: AÇÃO DECLARATÓRIA DE CONSTITUCIONALIDADE - PROCESSO OBJETIVO DE CONTROLE NORMATIVO ABSTRATO - A NECESSÁRIA EXISTÊNCIA DE CONTROVÉRSIA JUDICIAL COMO PRESSUPOSTO DE ADMISSIBILIDADE DA AÇÃO DECLARATÓRIA DE CONSTITUCIONALIDADE - AÇÃO CONHECIDA. - O ajuizamento da ação declaratória de constitucionalidade, que faz instaurar processo objetivo de controle normativo abstrato, supõe a existência de efetiva controvérsia judicial em torno da legitimidade constitucional de determinada lei ou ato normativo federal. Sem a observância desse pressuposto de admissibilidade, torna-se inviável a instauração do processo de fiscalização normativa "in abstracto", pois a inexistência de pronunciamentos judiciais antagônicos culminaria por converter, a ação declaratória de constitucionalidade, em um inadmissível instrumento de consulta sobre a validade constitucional de determinada lei ou ato normativo federal, descaracterizando, por completo, a própria natureza jurisdicional que qualifica a atividade desenvolvida pelo Supremo Tribunal Federal. - O Supremo Tribunal Federal firmou orientação que exige a comprovação liminar, pelo autor da ação declaratória de constitucionalidade, da ocorrência, "em proporções relevantes", de dissídio judicial, cuja existência - precisamente em função do antagonismo interpretativo que dele resulta - faça instaurar, ante a elevada incidência de decisões que consagram teses conflitantes, verdadeiro estado de insegurança jurídica, capaz de gerar um cenário de perplexidade social e de provocar grave incerteza quanto à validade constitucional de determinada lei ou ato normativo federal. (BRASIL, 2003).
}

REVISTA DO DIREITO PÚBLICO, Londrina, v.8, n.2, p.91-118, mai./ago.2013 
meio de consulta em relação à validade constitucional de determinada lei ou ato normativo. Assim, essa impossibilidade já se confirmava no voto do Ministro Néri da Silveira em seu voto na $\mathrm{ADC} \mathrm{n}^{\circ} 1$, conforme se colaciona:

É que, em realidade, não se tratando de consulta à Corte Suprema, mas de ação, com decisão materialmente jurisdicional, impõe-se, à instauração da demanda em exame, que se faça comprovada, desde logo, a existência de controvérsia em torno da validade ou não da lei ou ato normativo federal, nos Tribunais do País. Do contrário, o litígio não teria justificativa, na instância originária e única desta Corte, que se transformaria desse modo, em órgão de consulta prévia, acerca da constitucionalidade da lei ou ato normativo federal, para que os Poderes da República aplicassem a norma, com certeza de sua validade (BRASIL, 1995).

Nesse sentido, para propor a referida ação exige-se que as decisões de primeira instância tenham sido conflitantes a ponto de causar insegurança no Estado de Direito, criando um quadro de perturbação social e gerando incerteza quanto à constitucionalidade de determinada lei ou ato normativo federal em grandes proporções. Portanto, a controvérsia em torno da legitimidade deverá ser de tal gravidade que estremeça, sobremaneira, a presunção de sua constitucionalidade.

Em contrapartida, Zeno Veloso (2000, p.286), entende que "a existência de dúvida relevante ou de controvérsia grave não foi explicitamente apresentada como pressuposto de admissibilidade da ADC". Asseverando que, "este pressuposto é óbvio tratando-se de ação declaratória, e foi requerido através de interpretação que o STF deu ao Texto Constitucional”. Pois, para ele, se não houvesse tal requisito o STF funcionaria tão somente como órgão consultivo. O que desfiguraria sua natureza, não se enquadrando em sua principal tarefa de guardião da Constituição.

Outra decisão do STF que pode ser usada como parâmetro para análise do requisito relevante controvérsia judicial trata-se da $\mathrm{ADC}^{\circ} 18$, cujo objeto principal versava sobre o pedido de constitucionalidade do art. $3^{\circ} \S 2^{\circ}$ inciso, da Lei $n^{\circ} .9718 / 98$ para incluir no cálculo da COFINS, do ICMS repassado aos consumidores no preço dos produtos.

Nesta ação o Ministro Gilmar Mendes afiançou que a principal finalidade da ADC consistia na preservação da ordem jurídica constitucional, com vistas a afastar a insegurança jurídica ou o estado de incerteza sobre a 
validade de lei ou ato normativo federal. E que somente a partir desse quadro a jurisdição constitucional poderá ser provocada para pacificar a questão. ${ }^{6}$

Esse breve comentário do discurso do STF pode-se extrair que a dificuldade de se definir o que seja "relevante controvérsia judicial", se dá em virtude de caráter jurídico-político de suas decisões, em que se passa a analisar.

\subsection{A influência da natureza da decisão em Ação Declaratória de Constitucionalidade como fator de indeterminação do termo relevante controvérsia judicial}

Inicialmente, convém ressaltar que tendo o controle concentrado de constitucionalidade como seu principal instrumento a ação direta de inconstitucionalidade, em que há a intercessão entre o sistema político e jurídico, compreende-se que é da própria natureza do STF, em cada caso, decidir a respeito de disputas políticas, valendo-se de estrutura, critérios e procedimento inerentes ao sistema jurídico.

Assim, pelo fato desta Corte estar diante de conflitos políticos, suas decisões não se restringirão a simples natureza jurídica. Pois, em que pese a sua própria composição, ou seja, formado por membros indicados por um "chefe político", ainda sim é órgão do Poder Judiciário, ensejando, portanto, o acoplamento dos dois sistemas.

É necessário frisar ainda que para se chegar ao que seria o requisito da relevante controvérsia judicial não basta simplesmente manter o foco em números e dados estatísticos. Vez que, se assim o fosse, haveria muito mais Ações Declaratórias de Constitucionalidade que existem hoje, dado o indigitado número de ações de todo tipo que abarrotam o Judiciário, possuem decisões as mais dispares.

Gilmar Mendes (2000) entende que esse estado de insegurança não advém dos órgãos políticos competentes pela edição de textos normativos que dão

\footnotetext{
${ }^{6} \mathrm{O}$ manejo da referida ação somente se faz necessário quando houver controvérsia ou dúvidas relevantes sobre a constitucionalidade de determinado preceito, pois de outra forma, não há razão para movimentar a jurisdição constitucional. Ademais, além da existência de controvérsia a propositura da ADC deverá estar instruída com a comprovação deste requisito, sendo que sua ausência provocara a inépcia da inicial, em que se pode depreender do teor da decisão da Relatora, a Min. Cármen Lúcia Antunes Rocha na $\mathrm{ADC} \mathrm{n}^{\circ}$. 15, conforme consta: "De logo se conclui que o pedido não pode sequer ser apreciado na via eleita pela digna entidade Autora. A Lei n. 9.868/99 estabelece, em seu art. 14, que a petição inicial da ação declaratória de constitucionalidade indicará 'III. a existência de controvérsia judicial relevante sobre a aplicação da disposição objeto da ação declaratória'. Esta comprovação é imprescindível, pois, constitui elemento fundamental para que a ação possa ser recebida e conhecida. Sem ela a petição é inepta, por carecer de elemento essencial legalmente exigido" (BRASIL, 2007).
} 
fundamento a ação ou "da leitura e aplicação contraditória de normas legais pelos vários órgãos judiciais, mas da controvérsia ou dúvida que se instaura entre os órgãos judiciais, que de forma quase unívoca adotam uma dada interpretação".

Dessa forma, a controvérsia deve ser de tal relevância que possa afetar o princípio de presunção de constitucionalidade das leis e atos normativos.

Ora, conjectura-se, nesta vereda, que a justificativa fundamental da necessidade de demonstração da existência de controvérsia judicial relevante quando da proposição da $\mathrm{ADC}$ está na proteção do princípio da supremacia constitucional e da segurança jurídica.

Assim, tomando por base a teoria dos sistemas, de Niklas Luhmann (1983), bem como os termos acoplamento estrutural e legitimação através do procedimento, é cabal, inicialmente, realizar a fixação do significado desses institutos.

Para Luhmann, por ser a constituição um mecanismo complexo onde há a inteiração entre a política e o direito, que favorece a troca de conhecimentos, necessário se determinar qual seja o limite de cada sistema, em uma relação que possa se diferenciar o jurídico do político. Portanto, compete ao STF, situado no centro dessas trocas de informações, efetivar a constituição, sem, contudo, adentrar na individualidade dos sistemas.

Ocorre que o STF por ser Tribunal Constitucional é órgão que tem legitimidade, como já demonstrado anteriormente, para completar a pretensão negativa do legislador constituinte. Assim, em virtude da localização do Tribunal Constitucional Brasileiro, no cerne decisório do acoplamento estrutural, entre os subsistemas jurídico e político da sociedade complexa, pode-se afirmar, indubitavelmente, que suas decisões possuem caráter jurídico-político que decorrem da natureza inerente a este Tribunal.

Dessa forma, sendo o STF órgão central que visa dirimir os conflitos, deverá este estabelecer as adjacências das limitações, atuando como moderador entre os Poderes.

Ora, pela posição ocupada na sistemática da organização do Estado, o STF possui uma condição ambivalente. Logo, por estar nesse status privilegiado garante o pleno funcionamento dos "códigos da política e do direito" , com suas influências mútuas nos sistemas.

\footnotetext{
${ }^{7}$ Os termos utilizados aqui são os da dicção de Niklas Luhmann. (1985).
} 
Dessa forma, assevera Luhmann (2002, p.539-541) que é através da constituição que se estabelecem as zonas de contato entre o jurídico e o político. Estabelece-se uma recíproca irritabilidade entre esses dois subsistemas da sociedade. Desencadeiam-se maiores possibilidades do sistema jurídico registrar decisões políticas em forma jurídica, além da possibilidade de a política servirse do direito para concretizar seus objetivos.

A constituição, então seria comum a ambos os sistemas. E o tribunal, segundo a visão de Luhmann, seria o centro do sistema jurídico interno, onde os subsistemas se acoplariam em suas decisões.

Com efeito, em sendo o STF o Tribunal Constitucional, deverá proferir decisões no campo de conflito entre o político e o jurídico em virtude da indeterminabilidade de certos dispositivos constitucionais, como é o caso do requisito da $\mathrm{ADC}$ da relevante controvérsia judicial.

Conforme já ressaltado, pela sua própria forma de composição, O Processo da ADC é marcado por um fundo político, assim, pelo Texto Constitucional conferir ao STF a competência de "verificar a compatibilidade dos atos genéricos e abstratos em face da Lei Maior, independente da ocorrência de determinada situação concreta" (SLAIBI FILHO, 2000, p.200), depara-se com contínuos entraves de forças que giram entre o sistema político e jurídico, não alcançando seu principal objetivo.

O STF por vezes, em suas decisões em sede de ADC, deixa o requisito em análise sem uma definição palpável, o que demonstra a crise de identidade que vive o Tribunal Constitucional brasileiro, principalmente ante a crescente busca da sociedade em ver seus direitos adequadamente garantidos, ou seja, o STF encontra-se numa encruzilhada, pois de um lado os cidadãos premem que seus direitos sejam assegurados e, de outro a absolutização do princípio da separação de poderes acaba por engessar a atuação da Corte, pendendo inúmeras críticas quando suplanta a linha imaginária da imérita separação adentrando em questões do sistema político.

\section{CONSIDERAÇÕES FINAIS}

O controle de constitucionalidade desempenhado pelo Supremo Tribunal Federal vem, nas últimas décadas, ganhando uma elevação sem precedentes desde a criação deste Tribunal, este fato teve início com a Constituição Federal de 1988 e se ampliou em 1993 com a Emenda Constitucional no. 3, que veio instituir a Ação Declaratória de Constitucionalidade (ADC), posteriormente regulamentada pela Lei $n^{\circ}$. 9868/99 que lhe traçou as principais características. 
Dessa forma, vislumbra-se uma modificação no quadro do controle realizado, até então, em terra brasilis, em que havia a monopolização do controle difuso de constitucionalidade.

Com a regulamentação da ADC delineou-se um quadro deste controle exercido pelo STF totalmente novo - que fora completado com a Emenda Constitucional $n^{0}$ 45/04 -, iniciando-se o fenômeno da uniformização da jurisprudência pela Corte das matérias constitucionais que se contrariavam nas outras instâncias da Justiça. Como o requisito principal no qual devem ser fundamentadas as ações que visam declarar a constitucionalidade.

Assim, ante a análise do requisito da relevante controvérsia judicial em sede de ADC pôde-se aferir que o tema em questão não é pacifico na doutrina, muito menos na jurisprudência, entretanto, constata-se que o instrumento da ADC teve o intuito de reforçar os laços democráticos afeitos ao Supremo Tribunal Federal. Tribunal este com galhardia constitucional tamanha que numa democracia complexa, como a brasileira, em que, inicialmente, se buscou albergar na própria Constituição interesses tão díspares, o STF pretende assegurar não apenas o domínio da maioria, mas igualmente a consideração às minorias.

$O$ requisito deprecado e afirmado na $\mathrm{ADC}$ consiste na exigência de situação concreta que possa comprovar de fato a controvérsia judicial. Ou seja, a controvérsia judicial precisa existir de forma objetiva quanto a dúvida de diversos órgãos julgadores, não numericamente estatística, mas sua comprovação necessitará ser consistente, por meio decisões judiciais conflitantes sobre a mesma lei ou ato normativo federal.

Outro fator percebível na análise dessas decisões do STF está relacionada com a intensidade da controvérsia, no momento da aplicação da lei ou ato normativo. Ora, não basta posicionamento opostos. Exige-se que a dúvida leve a uma insegurança jurídica e incerteza sobre a validade da lei ou ato normativo federal em relação à Constituição Federal. A ponto de causar na sociedade sensação de desamparo, oscilação das decisões judiciais entre um e outro entendimento e ausência de segurança jurídica.

Porém, o STF como Tribunal Constitucional do quilate de seus membros não deve, em sede de $\mathrm{ADC}$, servir apenas de um órgão consultivo dos demais Poderes. Necessário se mencionar que em face do caráter jurídico-político das decisões proferidas pelo Tribunal Constitucional torna-se, por vezes, um tanto quando dificultoso se definir a relevante controvérsia judicial, até mesmo no seio do STF, pois em alguns de seus julgados dá a entender que esse requisito somente seria cogitado se houvessem dados estatísticos pra tanto. 
Com efeito, o requisito da relevante controvérsia judicial deveria ser tomado a partir de casos concretos que pudessem ferir, irremediavelmente, a Constituição, retirando-lhe parte de sua supremacia. Contribuindo para que o STF suplantasse a posição meramente virtual na tríade dos Poderes - situação tão levianamente desejada pelos demais Poderes -, elevando-se ao patamar de guardião mor da Constituição Federal, para que assim possa ser vislumbrado como um Tribunal com verdadeiro status de Corte Constitucional.

\section{REFERENCIAS}

AUGUSTO, Silma Maria. A Jurisdição como instrumento de efetivação das cotas raciais. 2010. Dissertação (Mestrado) - Instituição Toledo de Ensino, Bauru, 2010.

BARROSO, Luís Roberto. Curso de direito constitucional contemporâneo: os conceitos fundamentais e a construção do novo modelo. São Paulo: Saraiva, 2009.

. Interpretação e aplicação da Constituição. Fundamentos de uma dogmática constitucional transformadora. 5. ed. São Paulo: Saraiva, 1996.

BASTOS, Celso Ribeiro. Curso de direito constitucional. 17. ed. São Paulo: Saraiva, 1996.

BINENBOJM, Gustavo. A nova jurisdição constitucional brasileira. Legitimidade democrática e instrumentos de realização. Rio de Janeiro: Renovar, 2001.

BRASIL. Supremo Tribunal Federal. Ação declaratória de constitucionalidade $\mathbf{n}^{\mathbf{0}} \mathbf{1}$. Requerente(s): Presidente da República, Mesa do Senado Federal e Mesa da Câmara dos Deputados. Relator: Min. Moreira Alves. Diário da Justiça, Brasília, 16 jun. 1995. Disponível em: $<$ http:// www.stf.gov.br/jurisprudencia $>$. Acesso em: 11 out. 2010.

BRASIL. Supremo Tribunal Federal. Ação declaratória de constitucionalidade $n^{\mathbf{0}}$ 3. Requerente(s): Procurador-Geral da República. Relator: Min. Nelson Jobim. Diário da Justiça, Brasília, 9 maio 2003. 
Disponível em: $<$ http://www.stf.gov.br/ jurisprudencia $>$. Acesso em: 10 out. 2010.

. Supremo Tribunal Federal. Ação Declaratória de

Constitucionalidade $\mathbf{n}^{\mathbf{0}}$ 15. Relator: Ministra Cármen Lúcia Antunes Rocha. Diário da Justiça, Brasília, 15 mar. 2007. Disponível em: $<$ http:// www.stf.gov.br/jurisprudencia>. Acesso em: 7 out. 2010.

CANOTILHO, José Joaquim Gomes. Direito constitucional e teoria da Constituição. 7. ed. Coimbra: Almedina, 2003.

DANTAS, Ivo. O valor da constituição: do controle de constitucionalidade como garantia da supralegalidade constitucional. Rio de Janeiro: Renovar, 2001.

HÄBERLE, Peter. Hermenêutica Constitucional. A sociedade aberta dos intérpretes da Constituição: Contribuição para a interpretação pluralista e "procedimental" da Constituição. Porto Alegre: Sérgio Antonio Fabris, 2002.

HABERMAS, Jünger. A inclusão do outro: estudos de teoria política. São Paulo: Loyola, 2002.

. Direito e democracia: entre facticidade e validade. Rio de Janeiro: Tempo Brasileiro, 2003a. v. 1.

Direito e democracia: entre facticidade e validade, vol. II. Rio de Janeiro: Tempo Brasileiro, 2003b. v.2.

KELSEN, Hans. Jurisdição constitucional. São Paulo: Martins Fontes, 2003.

LEAL, Mônia Clarissa Hennig. Jurisdição constitucional aberta: reflexões sobre a legitimidade e os limites da jurisdição constitucional na ordem democrática - uma abordagem a partir das teorias constitucionais Alemã e Norte-Americana. Rio de Janeiro: Lumen Juris, 2007.

LUHMANN, Niklas. Legitimação pelo procedimento. Trad. Maria da Conceição Corte-Real. Brasília: Unb, 1980. 
. Sociologia do direito I. Trad. Gustavo Bayer. Rio de Janeiro: Tempo Brasileiro, 1983.

. Sociologia do direito II. Trad. Gustavo Bayer. Rio de Janeiro: Tempo Brasileiro, 1985.

. El derecho de la sociedad. Trad. Javier Torres Nafarrate. México: Universidad Iberoamericana, 2002.

MENDES, Gilmar Ferreira. Ação declaratória de constitucionalidade e demonstração da existência de controvérsia judicial. Revista Jurídica Virtual da Casa Civil. Brasília, v. 1, n. 9, fev. 2000. Disponível em: $<$ http:// www.presidencia.gov.br/CCIVIL_03/revista/Rev_09/Gilmar.htm>. Acesso em: 20 dez. 2008.

. Jurisdição constitucional: o controle abstrato de normas no Brasil e na Alemanha. 2. ed. São Paulo: Saraiva, 2007.

MÜLLER, Friedrich. Quem é o povo? A questão fundamental da democracia. 3. ed. São Paulo: Max Limonad, 2003.

OTTO, Ignácio. Derecho constitucional, sistema de fuentes. 2.ed. Barcelona: Ariel, 2001.

PINHO, Judicael Sudário de. Temas de direito constitucional e o Supremo Tribunal Federal. São Paulo: Atlas, 2005.

PIOVESAN, Flávia C. Proteção judicial contra omissões legislativa. 2.ed. São Paulo: Revista dos Tribunais. 2003.

ROTHERBURG, Walter Claudius. Inconstitucionalidade por omissão e troca de sujeito. São Paulo: Revista dos Tribunais, 2005.

. Velhos e novos rumos das ações de controle abstrato de constitucionalidade à luz da Lei no 9.868/99. In: SARMENTO, Daniel (Org.). O controle de constitucionalidade e a Lei $\mathbf{9 . 8 6 8 / 9 9}$. Rio de Janeiro: Lúmen Júris, 2002. 
SANTORO, Emílio. Estado de direito e interpretação: por uma concepção jusrealista e antiformalista do Estado de direito. Porto Alegre: Livraria do Advogado, 2005.

SILVA, José Afonso da. Curso de direito constitucional positivo. 34 ed. São Paulo: Malheiros, 2011.

SILVA, Maria de Lourdes Seraphico Peixoto da. Instrumento inconstitucional de controle de constitucionalidade. 1994. Apresentada ao Concurso para Professor do Departamento de Direito Público da Universidade Federal do Paraná. Curitiba, 1994.

SCARTEZZINI, Ana Maria. A Ação Declaratória de Constitucionalidade da lei e os princípios constitucionais. In: MARTINS, Ives Gandra da Silva; MENDES, Gilmar Ferreira (Coords). Ação declaratória de constitucionalidade. São Paulo: Saraiva, 1996.

SLAIBI FILHO, Nagib. Ação declaratória de constitucionalidade. 2.ed. Rio de Janeiro: Forense, 2000.

STRECK, Lênio Luiz. Jurisdição constitucional e hermenêutica: uma nova crítica do Direito. 2.ed. São Paulo: Forense, 2004.

TAVARES, André Ramos. Teoria da justiça constitucional. São Paulo: Saraiva, 2005.

TAVARES, André Ramos. Tribunal e jurisdição constitucional. São Paulo: Celso Bastos, 1998.

VELOSO, Zeno. Controle jurisdicional de constitucionalidade. 2.ed. Belo Horizonte: Del Rey, 2000.

Recebido em: 2012-04-13 Aprovado para publicação em: 2013-08-13

Como citar: MARTIN, Andréia Gracia; AUGUSTO, Silma Maria. Análise do requisito da relevante controvérsia judicial sem sede de ação declaratória de constitucionalidade. Revista do Direito Público, Londrina, v.8, n.2, p.91-118, mai/ ago.2013. DOI: 10.5433/1980-511X.2013v8n2p91. 